\title{
Atopic Eczema School - a New and Successful Patient Management Program
}

Psychosocial interventions can improve clinical outcomes of atopic dermatitis. This is the basis of patient education programs for atopic eczema. DeRMATOLOGY + Psychosomatics has published several studies in the past years [Hampel et al., 2001; Jaspers et al., 2000; Lemke et al., 2000; Salewski and Lissner, 2002; Zschocke et al., 2000]. The present issue of the journal focuses this topic and presents some of the latest developments in patient education programs.

The efficacy of relapse prevention has made educational interventions become widely adopted in the treatment of various diseases [Irvin et al., 1999; Williams and Schneiderman, 2002]. The effects of educational interventions on the self-management of asthma were demonstrated in a metaanalytic review by Guevara et al. [2003].

Evidence that psychosocial factors contribute to the development of atopic dermatitis comes from studies like those by Kodama et al. [1999], Kilpeläinen et al. [2002] and Picardi and Abeni [2001]. Kodama et al. [1999] questioned 1,457 patients after the Japanese earthquake in Hanshin in 1995. They found that $38 \%$ of patients with atopic eczema in the most severely hit region and $34 \%$ in a moderately hit region reported exacerbation, compared to only $7 \%$ in a control group without earthquake stress. However, $9 \%$ and $5 \%$ in the respective earthquake regions but only $1 \%$ in the control region reported a marked improvement of their atopic eczema. In a multiple regression analysis, subjective stress was a better predictor of exacerbation than genetic and treatment-related factors were. The results of that study show that stress apparently has an immunological effect which can also, though to a slighter extent, exert an opposite inflammatory effect.

The relation between stress and atopic eczema is underlined by studies that show that daily hassles can be associated with symptom severity [King and Wilson, 1991].

Atopic dermatitis produces a significant economic burden [Emerson et al., 2001], and has a high impact on the quality of life of patients and their relatives [Balkrishnan et al., 2003; Myon et al., 2004]. Quality of life in patients with atopic dermatitis is impaired more than in patients with other dermatological diseases [Augustin et al., 1999] and even more than in patients with other severe chronic diseases such as oncological diseases [Augustin et al., 2000] or juvenile diabetes mellitus [Su et al., 1997].

Besides, there is evidence that psychosocial stresses influence the development and course of atopic dermatitis via biologically plausible mechanisms [Buske-Kirschbaum et al., 2001; Gieler et al., 2000, 2002; Kupfer et al., 2001; Schmid-Ott et al., 2001]. Behavioral interventions and patient management programs help reduce the level of such psychosocial stresses and contribute to better clinical outcomes in atopic dermatitis.

The effects of combined psychotherapeutic interventions were investigated in a couple of studies, and a metaanalysis on that issue was published in DeRmatology + Psychosomatics by Gieler et al. [2000].

The poor knowledge of patients with atopic dermatitis regarding corticoid treatment [Beattie and Lewis-Jones, 2003; Basak et al., 2003] as well as non-compliance regarding its use [Charman et al., 2000] suggest that atopic dermatitis management programs are necessary to improve coping with and outcome of the disease.

The effects of hydrocortisone only therapy and hydrocortisone therapy plus self-control strategies on scratching were compared by Melin et al. [1986], and Noren and Melin [1989] investigated different topical applications including systemic steroids in comparison to a combined psychotherapy. The skin symptoms improved under all these treatments, but patients that received psychotherapy improved significantly more. The use of drugs decreased, systemic steroids were no longer used, even at 1-month follow-up.

In a well-controlled study Ehlers et al. [1995] compared the effects of different psychological and dermatological therapies

\begin{tabular}{ll}
\hline KARGER & ๑ 2004 S. Karger GmbH, Freiburg \\
$\begin{array}{l}\text { Fax +4976145207 14 } \\
\begin{array}{l}\text { E-mail Information@Karger.de } \\
\text { www.karger.com }\end{array}\end{array}$ & $\begin{array}{l}\text { Accessible online at: } \\
\text { www.karger.com/dps }\end{array}$
\end{tabular}

Prof. Dr. Uwe Gieler 
on atopic eczema. Dermatological symptoms and scratching frequency were reduced by all therapies under investigation, especially by combined behavior therapy and scratching control techniques, but also slightly better by behavior therapy than by dermatological education and school medical therapy. In a further study, scratching frequency was found to decline in one group while in another group itching, skin symptoms and scratching frequency improved more. In the first group, the psychological variables 'depression', 'fear of failure', 'restrictions through atopic eczema', 'lack of self-assurance and attractiveness' were reduced; dermatological state and itching improved only in individual cases. The psychological variables particularly improved following combined behavioral therapy and improved least in the control group. The fear tendency was most effectively reduced in those groups that received relaxation training or combined behavior therapy. In one study anxiety was improved by dermatological education and combination therapy, though not significantly. Follow-up after 6 and 12 months showed that psychotherapeutic interventions had better long-term effects on the course of the disease - the skin had improved further. The combination of behavioral therapy and education [Ehlers et al., 1995] and the combined behavior therapy yielded marginally better results than the other forms of psychotherapy.

The efficacy of therapies for children with atopic eczema and their parents has also been studied [Broberg et al., 1990; Chinn et al., 2002; Staab et al., 2002; Wenninger et al., 2000]. One study with children in a rehabilitation clinic compared the effects of a complex dermatological therapy with those of an additional behavior therapy comprising 7 hours per week. At the end of the treatment the skin had similarly improved in both treatment groups.

In two recent controlled studies educational measures were shown to be superior to routine therapy. One of the studies observed similar effects in two groups; one of the groups underwent a direct training to change behavior, the other group was educated by video tapes [Niebel, 2000]. In a randomized study with a total of 204 families it could be shown that maternal quality of life had significantly improved in the intervention groups as compared to the control group [Niebel, 1990]. In the last years, several studies on patient education programs in atopic dermatitis yielded similar results. Chavigny et al. [2002] studied 40 patients who participated in 'Atopic School', an atopic dermatitis education program that was developed in Nantes. The authors found an improvement in the SCORAD in $95 \%$ of the patients and concluded that the Atopic School 'represents a major breakthrough in the care of such patients'.

In the present issue of DeRmatology+Psychosomatics you will find more aspects regarding these treatment programs. The German Multicenter Study on Atopic Dermatitis has just been completed this year. It comprises more than 1,000 patients or affected parents and has yielded very similar results. This stimulates us to go on with this treatment approach. Atopic eczema is obviously an important psychosomatic disease. Further studies will help to highlight the missing link between affective state and psychoimmunological reactions.

Uwe Gieler, Gießen

Gerhard Schmid-Ott, Hannover

\section{References}

Augustin M, Zschocke I, Lange S, Seidenglanz K, Amon U: Quality of life in skin diseases: Methodological and practical comparison of different quality of life questionnaires in psoriasis and atopic dermatitis. Hautarzt 1999;50:715-722.

Augustin M, Zschoke I, Lange S, Seidenglanz K, Lange S, Schiffler A, Amon U: Validation and clinical results of the FLQA-d, a Quality of Life Questionnaire for patients with chronic skin diseases. Dermatol Psychosom 2000;1:12-19.

Balkrishnan R, Housman TS, Grummer S, Rapp SR, Clarke J, Feldman SR, Fleischer AB: The family impact of atopic dermatitis in children: The role of the parent caregiver. Pedatr Dermatol 2003;20: 5-10.

Basak PY, Ozturk M, Baysal V: Assessment of information and education about topical corticosteroids in dermatology outpatient departments: Experience from Turkey. J Eur Acad Dermatol Venereology 2003;17:652-658.

Beattie PE, Lewis-Jones MS: Parental knowledge of topical therapies in the treatment of childhood atopic dermatitis. Clin Exp Dermatol 2003;28:549553.

Broberg A, Kalimo K, Lindblad B, Swanbeck G: Parental education in the treatment of childhood atopic eczema. Acta Derm Venereol (Stockh) 1990; 70:495-499.
Buske-Kirschbaum A, Geiben A, Hellhammer D: Psychobiological aspects of atopic dermatitis: An overview. Psychother Psychosom 2001;70:6-16.

Charman CR, Morris AD, Williams HC: Topical corticosteroid phobia in patients with atopic eczema. $\mathrm{Br}$ J Dermatol 2000;142:931-936.

Chavigny JM, Adiceom F, Bernier C, Beons M, Stalder JF: Assessment of an educational program in an 'Atopic School': Pilot study in 40 patients. Ann Dermatol Venereol 2002;129:1003-1007.

Chinn DJ, Poyner T, Sibley G: Randomized controlled trial of a single dermatology nurse consultation in primary care on the quality of life of children with atopic eczema. Brit J Dermatol 2002;146: 32-439.

Ehlers A, Stangier U, Gieler U: Treatment of atopic eczema: A comparison of psychological and dermatological approaches to relapse prevention. J Consult Clin Psychol 1995;63:624-635.

Emerson RM, Williams HC, Allen BR: What is the cost of atopic dermatitis in preschool children? $\mathrm{Br} \mathrm{J}$ Dermatol 2001;143:514-522.

Gieler U, Stangier U, Ernst R: Psychosomatische Behandlung im Rahmen der klinischen Therapie von Hautkrankheiten; in Bosse K, Gieler U (Hrsg): Seelische Faktoren bei Hautkrankheiten. Bern, Huber, 1986.
Gieler U, Kupfer J, Niemeier V, Brosig B, Stangier U: Atopic eczema prevention programs - a new therapeutic concept for secondary prevention. Dermatol Psychosom 2000;1:138-147.

Gieler U, Niemeier V, Brosig B: Psychoimmunology and evaluation of therapeutic approaches; in Bieber T, Leung DYM (eds): Atopic Dermatitis. New York, Marcel Dekker, 2002

Guevara JP, Wolf FM, Grum CM, Clark NM: Effects of educational interventions for self management of asthma in children and adolescents: Systematic review and meta-analysis. BMJ 2003;326:13081309

Hampel P, Rudolph H, Petermann F, Stachow R: Stress management training for children and adolescents with atopic dermatitis during inpatient rehabilitation. Dermatol Psychosom 2001;2:116-123.

Irvin JE, Bowers CA, Bunn ME, Wang MC: Efficacy of relapse prevention: A meta-analytic review. J Consult Clin Psychol 1999;67:563-570.

Jaspers JPC, Span L, Molier L, Coenraads PJ: A multimodal education and treatment program for young adults with atopic dermatitis: A randomized controlled trial. Dermatol Psychosom 2000;2:148-154.

Kilpeläinen M, Koskenvuo M, Helenius H, Terho EO Stressful life events promote the manifestation of asthma and atopic diseases. Clin Exp Allergy 2002; 32:256-263. 
King RM, Wilson GV: Use of a diary technique to investigate psychosomatic relations in atopic dermatitis. J Psychosom Res 1991;35:697-706.

Kodama A, Horikawa T, Suzuki T, Ajiki W, Takashima T, Harada S, Ichihasha M: Effects of stress on atopic dermatitis: Investigations in patients after the great Hanshin earthquake. J Allergy Clin Immunol 1999;104:173-176.

Kupfer J, Gieler U, Braun A, Niemeier V, Huzler C, Renz H: Stress and atopic eczema. Int Arch Allergy Immunol 2001;124:353-355.

Lemke R, Peter M, Tirre A, van den Busche H, Alpers E, Defaie E, Grasselli M, Haupt G, Leuschner C, Meißner U, Stephan U, Wolf M, Breitbart EW Training of patients with atopic dermatitis and psoriasis vulgaris in an ambulant neighborhood rehabilitation program: Presentation of a pilot project. Dermatol Psychosom 2000;2:163-172.

Melin L, Frederiksen T, Noren P, Swebolius BG: Behavioural treatment of scratching in patients with atopic dermatitis. Br J Dermatol 1986;115:467-474.

Myon E, Taieb C, Macy G, Sibaud V: Atopic dermatitis and patient education: European evaluation in young children. J Eur Acad Derm Venereol 2004; 18(S1):77.
Niebel G: Verhaltensmedizinisches Gruppentraining für Patienten mit Atopischer Dermatitis in Ergänzung zur dermatologischen Behandlung. Pilotstudie zur Erprobung von Selbsthilfestrategien. Verhaltensmod Verhaltensmed 1990;11:24-44.

Niebel G: Entwicklung verhaltensorientierter Gruppentrainingsprogramme für $\mathrm{AD}$-Patienten - eine experimentelle Studie; in Niebel G (Hrsg): Behavior Medicine of Chronical Dermatological Disorders - Interdisciplinary Perspectives on Atopic Dermatitis and Its Treatment. Bern, Huber, 1990, pp 420-525.

Niebel G: Direkte versus videovermittelte Elternschulung bei atopischem Ekzem im Kindesalter als Ergänzung fachärztlicher Behandlung. Hautarzt 2000;51:401-411.

Noren P, Melin L: The effect of combined topical steroids and habit-reversal treatment in patients with atopic dermatitis. Br J Dermatol 1989;121: 359-366.

Picardi A, Abeni D: Stressful life events and skin diseases: Disentangling evidence from myth. Psychother Psychosom. 2001;70:118-136.

Salewski C, Lissner A: Coping with chronic illness processes underlying perceived stress and coping behaviour in adolescents with atopic eczema. Dermatol Psychosom 2002;3:132-138.
Schmid-Ott G, Jäger B, Meyer S, Stephan E, Kapp A, Werfel T: Different expression of cytokine and membrane molecules by circulating lymphocytes on acute mental stress in patients with atopic dermatitis in comparison to healthy controls. J Allergy Clin Immunol 2001;108:455-462.

Staab D, von Rueden U, Kehrt R, Erhart M, Wenninger K, Kamtsiuris P, Wahn U: Evaluation of a parental training program for the management of childhood atopic dermatitis. Pediatr Allergy Immunol 2002;13:84-90.

Su JC, Kemp AS, Varigos GA, Nolan TM: Atopic eczema: Its impact on the family and financial cost. Arch Dis Child 1997;76:159-162.

Wenninger K, Kehrt R, von Rüden U, Lehmann C, Binder C, Wahn U, Staab D: Structured parent education in the management of childhood atopic dermatitis: The Berlin model. Patient Edu Couns 2000; 40:253-261.

Williams RB, Schneiderman N: Resolved: Psychosocial Interventions can improve clinical outcomes in organic disease. Psychosom Med 2002;64:552-557.

Zschocke I, Fölster-Holst C, Esser C, Ravens-Sieberer $\mathrm{U}$, Lorenz B, Miltenburger C, Bullinger M, Augustin M: Attitudes and experiences towards corticoid treatment among parents of children with atopic dermatitis. Dermatol Psychosom 2000;2 155-162. 